\title{
Chronotype change in university students in the health area with excessive daytime sleepiness
}

Alteração do cronotipo em universitários da área da saúde com sonolência diurna excessiva

\author{
Marília Rocha Kintschev' (D) | mariliakintschev@hotmail.com \\ Suellen Suemi Shimada' (1) suemi_sh@hotmail.com \\ Maria Olivia da Silva' (1) mariaolivia.med@gmail.com \\ Yara Viñé de Barros' 1 (1) yaraviine@gmail.com \\ Hugo Dias Hoffmann-Santos' 10 hugo.epidemio@gmail.com
}

\begin{abstract}
Introduction: Excessive daytime sleepiness (EDS) is characterized by an increased likelihood of initiating sleep at inappropriate times through involuntary naps and it negatively impacts performance in studies, work, family, and social relationships and increases the risk of accidents.

Objective: This study evaluated the schedule and prevalence of EDS and its associated factors in medical students (using the PBL method), comparing it with students from other health courses (using the Traditional method).

Methods: A cross-sectional study was carried out with 1152 university students who were attending courses in the health area. The presence of EDS was defined when scores $>10$ in the Epworth Sleepiness Scale (ESS) and the chronotype was assessed by means of the MorningnessEveningness Questionnaire (MEQ). Using Stata 13.0 software, descriptive statistics, bivariate and multivariate analyses were performed, including interactions to fit the model.

Results: The prevalence of EDS was $56.5 \%$ (95\% Cl, 53.6-59.4), and the mean ESS score was 11.1 (95\% Cl, 10.8-11.3). This value was lower among those who had morning chronotypes and was higher among medical students. $10.3 \%(n=119)$ of the students had a chronotype that was incompatible with the period of the course. The associated and independent factors for EDS were: female gender (PR, 1.14, 95\% Cl, 1.01-1.29), age between 16 and 19 years (PR, 1.20,95\% Cl, 1.04-1.39), studying late at night and using cell phones before falling asleep (PR, 1.56, 95\% Cl, 1.02-2.38), not doing weekly physical activity ( $\mathrm{PR}, 1.13,95 \% \mathrm{Cl}, 1.02-1.25)$, and morning chronotype ( $\mathrm{PR}, 0.87,95 \% \mathrm{Cl}, 0.76-0.99)$. Not using cell phones before bedtime reduced the prevalence of EDS by $14 \%$.
\end{abstract}

Conclusions: This study demonstrated that the morning chronotype behaved as an independent protective factor for disorders of the circadian cycle. Performing weekly physical activity reduces EDS among students with intermediate and evening chronotypes.

Keywords: Disorders of Excessive Somnolence; Health Occupations Students; Circadian Rhythm Disorders; Chronotypes.

\section{RESUMO}

Introdução: A sonolência diurna excessiva (SDE) é caracterizada por uma maior probabilidade de o indivíduo iniciar o sono em horários inadequados por meio de cochilos involuntários, afeta negativamente o desempenho nos estudos, no trabalho e nas relações familiares e sociais, e aumenta o risco de acidentes.

Objetivo: Este estudo teve como objetivo avaliar o cronotipo e a prevalência de SDE e seus fatores associados em estudantes de Medicina (método PBL). Para tanto, compararam-se os discentes de Medicina com os de outros cursos da área da saúde (método tradicional).

Métodos: Trata-se de estudo transversal com 1.152 estudantes universitários matriculados em cursos de graduação da área da saúde. Definiu-se a presença de SDE quando se observaram escores > 10 na Epworth Sleepiness Scale (ESE), e o cronótipo foi avaliado por meio do instrumento Morningnesseveningness Questionnaire (MEQ). Por meio do software Stata 13.0, realizaram-se estatística descritiva e análises bivariadas e multivariadas, além de interações para que o estudo pudesse se ajustar ao modelo.

Resultados: A prevalência de SDE foi de 56,5\% (IC 95\%, 53,6-59,4), e a pontuação média na ESE foi de 11,1 (IC 95\%, 10,8-11,3). Esse valor foi menor entre os que apresentaram cronotipo matutino e maior entre os estudantes de Medicina. Dos alunos que participaram do estudo, 10,3\% ( $n=119)$ apresentaram um cronotipo incompatível com o período do curso. Os fatores associados e independentes para a SDE foram: sexo feminino (RP, 1,14, IC 95\%, 1,01-1,29), idade entre 16 e 19 anos (RP, 1,20, IC 95\%, 1,04-1,39), hábito de estudar de madrugada, uso de celular antes de dormir (RP, 1,56, IC 95\%, 1,02-2,38), não praticar atividade física semanal (RP, 1,13, IC 95\%, 1,02-1,25) e cronótipo matutino (RP, 0,87, IC 95\%, 0,76-0,99). Não usar telefones celulares antes de dormir reduziu a prevalência de SDE em $14 \%$.

Conclusões: Este estudo demonstrou que o cronotipo matutino se comportou como um fator protetor independente para distúrbios do ciclo circadiano. A prática de atividade física semanal reduziu a prevalência SDE entre universitários com cronotipos intermediário e noturno.

Palavras-chave: Distúrbio de Sonolência Excessiva; Estudantes da Área da Saúde; Distúrbio do Ciclo Circadiano; Cronotipo.

${ }^{1}$ Centro Universitário de Várzea Grande, Várzea Grande, Mato Grosso, Brazil.

Received on 07/16/20; Accepted on 12/21/20. | Evaluated by the double blind review process. 


\section{INTRODUCTION}

Although sleep is a modulator of neuroendocrine function, psychosocial behavior, and a regulator of metabolism and cell renewal, modern behavior has reduced its quantity and quality ${ }^{1}$. Although the extent of the mechanisms involved in sleep, its induction, and its control remain unknown, the biopsychosocial consequences of not sleeping are well understood, and various aspects of sleep have been deduced ${ }^{2}$. Sleep comprises a part of the circadian rhythm and is nonproportionally intercalated with a wakefulness period; this rhythm is regulated by the presence or absence of light ${ }^{3}$.

Sleep disorders have a high prevalence and serious negative impacts; however, few patients with sleep disorders receive treatment, which is usually only pharmacological and is associated with a risk of complications related to tolerance and dependence 4 . Excessive daytime sleepiness (EDS), or hypersomnia, is characterized by an increased likelihood of initiating sleep at inappropriate times through involuntary naps ${ }^{5}$. EDS negatively impacts performance in studies, work, family, and social relationships and increases the risk of accidents $^{6}$. The estimation of EDS prevalence is influenced by the measurement method, the assessed age range and the geographic region of residence: in South America, prevalence rates of up to $21 \%$ are reported in Mexico and in Brazil, it is reported in $17 \%$ of the population aged over 17 years ${ }^{7}$. Studies have reported a negative association between the presence of EDS and the quality of life of individuals with cardiac, respiratory or chronic noncommunicable diseases ${ }^{8,9}$.

Behaviors associated with higher education routine and its consequent psychosocial effects can promote circadian desynchronization of the individual's physiological chronotype and increase the likelihood of EDS ${ }^{10}$. The migration of the morning chronotype towards the evening chronotype can increase the risk of EDS among university students; therefore, the knowledge of this epidemiological profile is the initial step to promote quality of life ${ }^{11}$.

\section{METHODS}

\section{Study design}

This was a cross-sectional epidemiological study that evaluated the prevalence of EDS in university students from a private education institution in the Metropolitan Region of the Cuiabá River Valley, between August 2016 and July 2017.

Considering an estimated population of 7,000 college students, a prevalence of EDS equal to $50 \%$, an acceptable margin of error of $5 \%$, a design effect of 1.5 , and clusters equal to 1 , the sample size was calculated as 546 college students, who were required for a $95 \%$ confidence level, using Epi Info 7 software (CDC, Atlanta, USA). To reduce the probability of typing errors, double data entry was adopted.

The sample comprised undergraduate students in the health area who consented to participate in the study, and the evaluation instruments that were incorrectly filled out were excluded (Figure 1). Medical students were compared to students from other courses in the health area. In this teaching institution, the medical course uses the problem-based learning (PBL) method in comparison with other health courses, which used the traditional teaching method. The questionnaires were applied during the students' routine class schedule and they were invited to participate preferably near the middle of the course semester.

\section{Ethical aspects}

The present study was submitted to the Ethics and Research Committee (CEP) and approved under number 61275516.4.0000.5692. The questionnaires were applied during classes or 15 minutes before their beginning, the students received the evaluation instruments after completing the informed consent form, which contained information about the research and filling instructions.

Figure 1. Flowchart of selection of study participants.

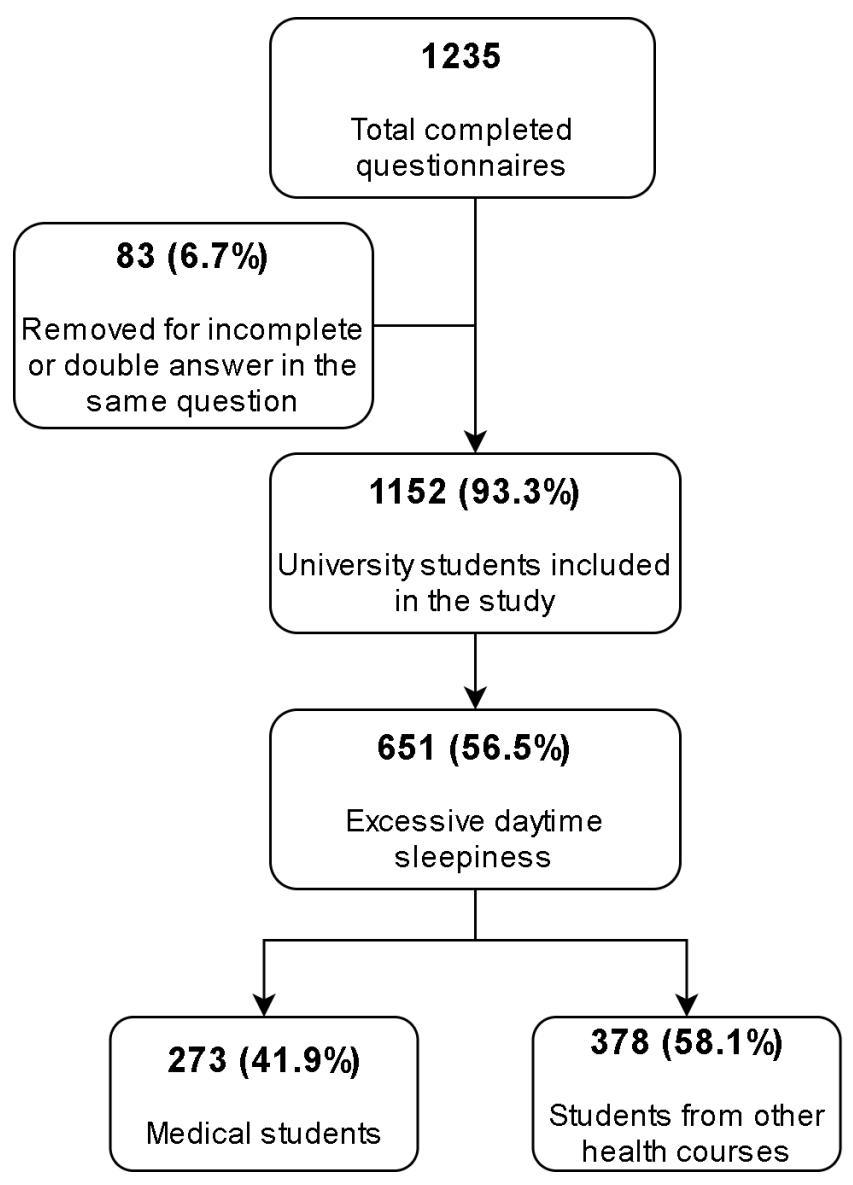




\section{Evaluation instruments}

Two self-reporting questionnaires with sociodemographic questions were applied. The first, called the MorningnessEveningness Questionnaire (MEQ) by Horne and Östberg (1976), was translated and adapted by the Institute of Biomedical Sciences of USP ${ }^{12}$. This questionnaire is the most frequently used instrument and has been validated worldwide for the identification of chronotypes. It contains 19 self-reporting questions, with a value being assigned to each answer, of which sum ranges from 16 to 86 . Scores above 58 classify individuals as morning type, below 42 as evening, and 42 to 58 as intermediaries or indifferent types. The definite morning chronotype was defined by scores between 70-86 and the definite evening chronotype by scores between 16-30.

The evaluation instrument called Epworth Sleepiness Scale (ESS) was used to evaluate the prevalence of EDS. The ESS is a questionnaire based on observations related to the nature and occurrence of daytime sleepiness. This selfadministered questionnaire assesses the probability of falling asleep in eight situations that involve daily activities; its overall score ranges from 0 to 24 and, according to its creators, scores above 10 suggest EDS. It is a widely used instrument, easy to understand, quickly completed, and its validation and translation into Portuguese included the young population (18 years or older) ${ }^{13}$.

\section{Statistical analysis}

The two-proportion test was used to check prevalence equality. Age was categorized into age groups according to the $25^{\text {th }}$, $50^{\text {th }}$, and $75^{\text {th }}$ percentiles. The course was categorized as "Medicine" and "Others from the health area" (Nursing, Speech therapy and Audiology, Pharmacy, Dentistry or Biomedical Sciences).

After using the Shapiro-Wilk test to assess the type of distribution of continuous variables, the unpaired Student's $t$ test or its non-parametric analog, the Mann-Whitney test, was used to evaluate the statistical difference of numerical variables with two categories. ANOVA or its non-parametric analog, Kruskal-Wallis, was used to check the statistical difference in variables with three or more categories.

The bivariate analysis was performed using Pearson's chi-square test, to assess the association between exposures and outcomes. To estimate the strength of association, the prevalence ratio (PR) and their respective 95\% confidence intervals $(95 \% \mathrm{Cl})$ were used. To determine the independent effect of explanatory variables on the response variable, Poisson regression with robust variance ${ }^{14}$ was used to adjust the covariates. The variables selected for this model had $p$ values $\leq 0.20$ in the bivariate analysis or biological plausibility. A value of $p<0.05$ was considered significant in the two-tailed test. The data were analyzed using Stata Statistical Software ${ }^{\circledR}$, version 12.0 (College Station, Texas, USA).

\section{RESULTS}

A total of 1,152 university students were assessed, with a mean age of 23.4 years $(95 \% \mathrm{Cl}, 23.0-23.8)$. The prevalence of EDS was $56.5 \%(95 \% \mathrm{Cl}, 53.6-59.4)$ and the mean ESS score was 11.1 (95\% Cl, 10.8-11.3). Students with a morning chronotype had statistically lower sleepiness scores than those with evening or intermediate chronotypes (Figure 2). Medical students had a statistically higher mean ESS scores than university students from other health courses (Figure 3); however, both mean scores were above the cutoff point that classifies the presence of EDS.

Figure 2. Mean score and $95 \% \mathrm{Cl}$ of the Epworth sleepiness scale according to the chronotype of university students attending health courses.

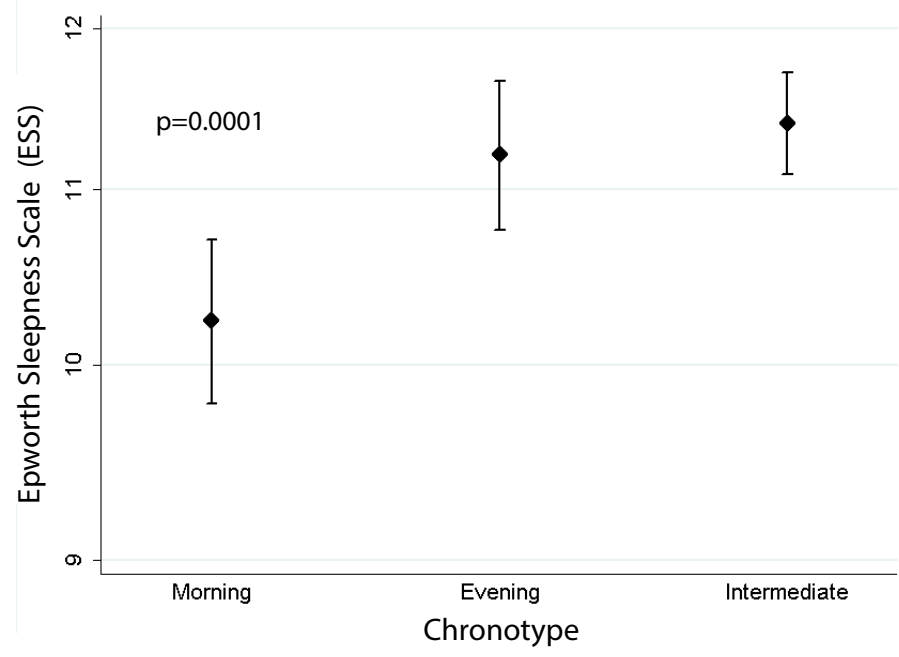

Figure 3. Mean score and $95 \% \mathrm{Cl}$ of the Epworth sleepiness scale according to the course attended by the university students from the health area.

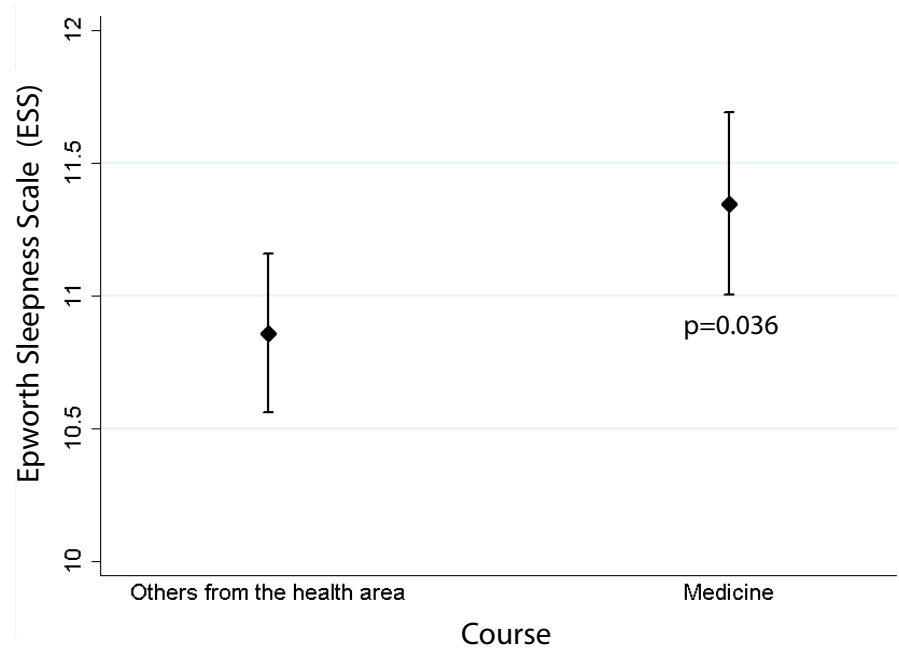


In the bivariate analyses, the variables gender, age, day period, performance of physical activity at least once a week, cell phone use at bedtime, use of stimulants to study, and chronotype showed an association with the presence of EDS (Table 1). Of the students whose morning circadian cycle started with a wakefulness period between 8:30 am

Table 1. Bivariate analysis of factors associated with excessive daytime sleepiness (EDS) among university students in the health care area.

\begin{tabular}{|c|c|c|c|c|}
\hline \multirow{2}{*}{ Variables } & \multirow{2}{*}{ Total (\%) } & \multirow{2}{*}{$\begin{array}{c}\text { Presence of EDS } \\
\mathbf{n}(\%)\end{array}$} & \multirow{2}{*}{$\begin{array}{c}\text { Absence of EDS } \\
\mathbf{n}(\%)\end{array}$} & \multirow{2}{*}{$\mathbf{p}$} \\
\hline & & & & \\
\hline Gender & & & & 0.017 \\
\hline Female & $828(71.9)$ & $486(58.7)$ & $342(41.3)$ & \\
\hline Age group & & & & 0.002 \\
\hline$>19$ e $<25$ years & $517(44.9)$ & $216(41.8)$ & $301(58.2)$ & \\
\hline$\geq 25$ years & $312(27.1)$ & $161(51.6)$ & $151(48.4)$ & \\
\hline Distance from home to college & & & & 0.31 \\
\hline$\leq 10$ kilometers & $703(61.0)$ & $393(55.9)$ & $310(44.1)$ & \\
\hline$>10$ kilometers & $449(39.0)$ & $258(57.5)$ & $191(42.5)$ & \\
\hline Others from the health area & $673(58.4)$ & $378(56.2)$ & $295(43.8)$ & \\
\hline Day period & & & & 0.031 \\
\hline Fulltime & $694(60.3)$ & $406(58.5)$ & $288(41.5)$ & \\
\hline Morning & $270(23.4)$ & $155(57.4)$ & $115(42.6)$ & \\
\hline Night & $188(16.3)$ & $90(47.9)$ & $98(52.1)$ & \\
\hline Course year & & & & 0.58 \\
\hline $1^{\text {st }}$ year & $397(34.5)$ & $227(57.2)$ & $170(42.8)$ & \\
\hline $2^{\text {nd }}$ year & $208(18.0)$ & $124(59.6)$ & $84(40.4)$ & \\
\hline $3^{\text {rd }}$ year & $230(20.0)$ & $130(56.5)$ & $100(43.5)$ & \\
\hline Yes & $1036(89.9)$ & $600(57.9)$ & $436(42.1)$ & \\
\hline No & $116(10.1)$ & $51(44.0)$ & $65(56.0)$ & \\
\hline Studies after midnight & & & & 0.101 \\
\hline Yes & $759(65.9)$ & $442(58.2)$ & $317(41.8)$ & \\
\hline No & $393(34.1)$ & $209(53.2)$ & $184(46.8)$ & \\
\hline Uses stimulants to study? & & & & 0.019 \\
\hline Yes & $345(30.0)$ & $213(61.7)$ & $132(38.3)$ & \\
\hline No & $807(70.0)$ & $438(54.3)$ & $369(45.7)$ & \\
\hline Chronotype & & & & 0.013 \\
\hline Morning & $299(25.9)$ & $148(49.5)$ & $151(50.5)$ & \\
\hline Evening & $282(24.5)$ & $161(57.1)$ & $121(42.9)$ & \\
\hline Intermediate & $571(49.6)$ & $342(59.9)$ & $229(40.1)$ & \\
\hline
\end{tabular}


and 11:30 am (evening chronotype), 14.1\% (38/270) attended health courses. Of the students whose evening circadian cycle started with a sleeping period between 9:00 pm and 10:45 pm (morning chronotype), 43.1\% (81/188) attended health courses. The distribution of students according to their chronotypes and the day period is shown in Figure 4.

The independent factors associated with the prevalence of EDS were: female gender, age $<19$ years old, studying late at night and using cell phones before falling asleep, not doing weekly physical activity, and having a morning chronotype, with the latter being the only protective factor (table 2).

The prevalence of EDS was similar between males and females among medical students (PR, 1.06. 95\% Cl, 0.90-1.24; $\mathrm{p}=0.46$ ); however, it was $30 \%$ higher among female students from other courses in the health area when compared to male students from other health area courses (PR, 1.30, 95\% $\mathrm{Cl}, 1.07-1.59, \mathrm{p}=0.004)$.

Students with morning chronotypes who did not perform physical activities had a prevalence of EDS that was statistically similar to students with morning chronotypes who were physically active ( $\mathrm{PR}, 0.99,95 \% \mathrm{Cl}, 0.78-1.25, \mathrm{p}=0.95)$. Students with intermediate chronotypes who did not perform physical activities had a prevalence of EDS that was $25 \%$ higher than students with intermediate chronotypes who were physically active (PR, 1.25, 95\%Cl, 1.02-1.52, $\mathrm{p}=0.03)$. Students with evening chronotypes who did not perform physical activities had a prevalence of EDS that was statistically similar to students with evening chronotypes who were physically active (PR, 1.14, 95\%Cl, 0.99-1.30, $\mathrm{p}=0.06$ ).

For students who did not use cell phones before falling asleep, the prevalence of EDS decreased by $14 \%$ (ARR, 0.14, $95 \% \mathrm{Cl}, 0.04-23.4)$.

\section{DISCUSSION}

Population data show that one in five people have EDS, which reduces the individual's ability to maintain an ideal level of wakefulness during the day, negatively impacting their health and quality of life ${ }^{15}$. University students need good quality of attention and concentration for the teachinglearning process to be effective.

Using the same definition as our outcome in this study, a cohort study of Korean adults ${ }^{16}$ identified the prevalence of EDS as equal to $12.2 \%$ and found that the following factors were associated with EDS: older age, intense physical activity, poor education, habitual snoring, and poor sleep perception. In Australian adults ${ }^{17}$, the prevalence of EDS is $10.4 \%$ among men and $13.6 \%$ among women, and its total incidence is $5.1 \%$ in the age group of 20-29 years. This age group comprises the majority of those attending college and, in the present study, the
Figure 4. Distribution of students in the health area evaluated according to the period of the course and the chronotype

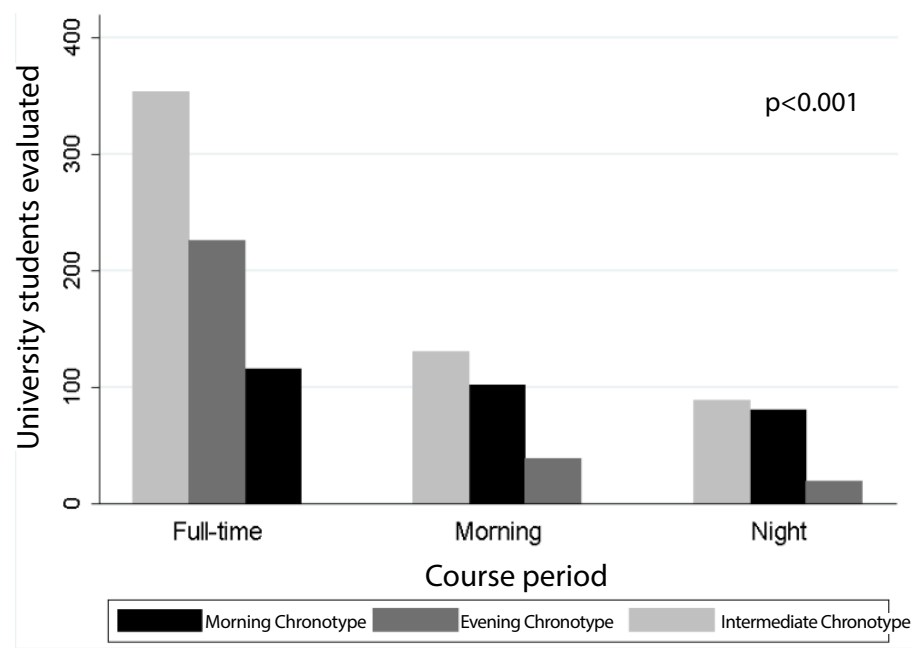

Table 2. Multivariate analysis of the variables associated with excessive daytime sleepiness in university students in the health area.

\begin{tabular}{cccc}
\hline Independent variables & PR-adjusted & $\mathbf{9 5 \%} \mathrm{Cl}$ & $\mathbf{p}$ \\
\hline Gender & & & \\
Male & 1.00 & & \\
Female & 1.14 & $1.01-1.29$ & 0.03 \\
\hline Age group & & & \\
16-19 years & 1.20 & $1.04-1.39$ & 0.01 \\
$>19$ and $<25$ years & 1.15 & $0.99-1.33$ & 0.06 \\
$\quad \geq 25$ years & 1.00 & & \\
\hline
\end{tabular}

Studies after midnight and uses the cell phone before falling asleep

\begin{tabular}{lccc} 
No and Yes & 1.45 & $0.94-2.24$ & 0.09 \\
Yes and No & 1.43 & $0.89-2.29$ & 0.14 \\
Yes and Yes & 1.56 & $1.02-2.38$ & 0.04 \\
No and No & 1,00 & - & - \\
\hline
\end{tabular}

Weekly physical activity performance

\begin{tabular}{cccc} 
Does not perform & 1.13 & $1.02-1.25$ & 0.02 \\
Performs & 1.00 & & \\
\hline
\end{tabular}

Chronotype

\begin{tabular}{cccc} 
Morning & 0.87 & $0.76-0.99$ & 0.05 \\
Evening & 0.92 & $0.82-1.04$ & 0.21 \\
Intermediate & 1.00 & & \\
\hline
\end{tabular}

*PR: prevalence ratio. Cl95\%: 95\% confidence interval.

prevalence of EDS in this age group was 56.4\% (367/651). This rate is about 11-fold higher than that of the Australian study.

The high variation in the prevalence of EDS (0.5-36\%) between several studies can be explained by the fact that there 
is no standardization for its detection, since different evaluation instruments can be used; however, studies that use ESS scores $>10$ as a criterion generally report relatively low prevalence rates of $\mathrm{EDS}^{16}$. This aspect further reinforces the importance of the high prevalence that was identified in the present study, since the diagnostic criterion that tends to not overestimate the presence of EDS was used.

A Brazilian study of 1066 individuals $^{18}$ identified a prevalence of EDS equal to $16.8 \%$, and the prevalence was statistically higher $(\mathrm{OR}=2.33,95 \% \mathrm{Cl}=1.64-3.32, \quad \mathrm{p}<0.001)$ in women $(21.7 \%)$ than men $(10.6 \%)$. The study reported a statistically similar prevalence of EDS for different age groups, marital status, and levels of schooling. Likewise, the present study identified a 14\% higher prevalence of EDS in female students, but in disagreement with the aforementioned study, a 20\% higher prevalence of EDS was identified among those aged up to 19 years, compared to those aged 25 years or older. This difference can be understood when considering that the behavior of these two age groups reflects their current stage of life with respect to neurocognitive development and emotional maturation.

The behavior imposed by the university routine itself may not promote the differences that could explain the prevalence of higher EDS in women, but the quality of mental health may have an important influence. A study conducted with 4,001 Brazilians identified that depressive disorders showed a $155 \%$ higher rate in women than men ${ }^{19}$, and the authors added sleep disorders to those of depressive disorder symptoms. In 2015 in the United States, the prevalence of severe mental disorders in women was almost two-fold that that in men, and the prevalence of any mental disorder was almost $50 \%$ higher in women than men ${ }^{20}$. This suggests that men and women have distinct emotional health statuses, which can be reflected by the higher prevalence of EDS in women ${ }^{21}$.

A study that evaluated 172 medical students ${ }^{11}$ observed that the group of students with EDS at the end of the semester had worse academic performance than the group without it. In the present study, the prevalence of EDS in medical students was statistically similar to the prevalence of EDS in students from other health courses; however, the ESS score was statistically higher in medical students, although both mean values exceeded the cutoff for a probable diagnosis of EDS (ESS score $>10$ ). Medical school utilizes an active teaching methodology (Problem Based Learning - PBL) that differs from the other health courses of the evaluated institution, which use a traditional method. Therefore, it is likely that the teaching methodology did not impact the development of EDS in university students in the health area.

In a prior meta-analysis ${ }^{22}$, it was found that physical activity acutely improved all the measurements related to sleep quality in healthy individuals. Physical activity provides immediate benefits to the lives of individuals and can be used as an intervention for the treatment of EDS or other sleep disorders. The present study confirms the importance of this intervention by demonstrating a 13\% higher prevalence of EDS among students who did not perform weekly physical activity. Among students with the intermediate chronotype (sleep onset between 10:45 pm and 12:45 am), the prevalence of EDS was $25 \%$ higher in those who did not perform weekly physical activity. The prevalence of EDS in students with morning chronotype who performed weekly physical activity was $6.5 \%$ (75/1152). Therefore, the late sleep onset, along with a sedentary lifestyle, increases the prevalence of EDS by $284 \%$.

There was no statistically significant difference between the prevalence of EDS and study period, which meant that the distribution of poor sleep quality was homogeneous. This emphasizes the importance of carrying out educational actions throughout the higher education course, which have practical applications for everyday student life.

Individuals with a definite morning chronotype usually go to sleep before 10:00 pm and wake up before 6:00 am. High school students showed brain activity with higher alpha power during morning classes, reducing brain activity throughout the day, suggesting that better cognitive development occurs in the morning ${ }^{23}$. Of every three individuals with definite morning chronotypes, one studies at night, probably due to the need to work during the day to pay for their academic training. Thus, students with this type of chronotype who take night classes are studying during the period of their circadian cycle when the serum concentration of melatonin is gradually increasing, which reduces their selective attention and decreases their learning efficacy. This combination of factors may cause the apparent demotivation that was observed in some of the students who participated in the discussions promoted by the teacher or who stayed until the end of the classes. Continuous exposure to academic evening routines and the creation of an emotional link between the future benefits of higher education degrees are factors that may promote the desynchronization of the normal circadian cycle and chronotype migration.

In contrast, the definite evening chronotype is associated with a late sleep onset (between 2:00 and 3:00 am), so its natural awakening also occurs later (between 10:00 and 11:00 am). It turns out that eight of ten students who were evaluated participated in full-time or morning courses and therefore needed to wake up much earlier than the time for which their body was accustomed. The students thus started academic activities with a high concentration of melatonin circulating through their bodies, which may explain their high consumption of caffeine products. 
Most interviewed students had an intermediate chronotype (49.6\%), which suggests a probable chronobiological transition due to the accumulation of desynchronization behaviors and the circadian pattern of sleep stimulation by the absence of light. Cohort studies may assess whether college students who change from a morning to intermediate or evening chronotype improve from the beginning to the end of a course.

Although the mean ESS of students with morning chronotype was within the range of values used to define EDS, it was statistically lower than the mean ESS of students with intermediate or evening chronotypes. Indeed, the morning chronotype reduced the prevalence of EDS by $13 \%$ compared to the intermediate chronotype. Individuals who used cell phones before bed and studied until late at night had a of $56 \%$ prevalence of EDS. The inefficient use of the physiological period of sleep for learning activities may be due to the extensive list of extra-class tasks that are required of the students and because they have no other free time to do them.

In Turkish medical students ${ }^{24}$, EDS was more prevalent in female subjects, in agreement with the observations of the present study. A high prevalence of EDS was detected in precollege students $(55.8 \%)^{25}$, which shows the origin of the sleep disorder occurred before the start of higher education. Among pre-college individuals, the factors associated with EDS were alcohol intake and smoking, and there was no association with gender, age, and depression.

The evaluation of 217 Colombian medical students ${ }^{26}$ found that sleep efficiency of less than $65 \%$ increased the occurrence of low academic performance by $323 \%$. In the aforementioned study, the prevalence of EDS was equal to $49.8 \%$ and the mean ESS was equal to 8.4, which were lower than those observed in the present study. Another study, in turn, suggests that improved sleep quality is able to reduce students' low academic performance ${ }^{27}$. Although the present study did not assess academic performance, its causal relationship with EDS has been increasingly consolidated.

Not using a cell phone before bed would reduce the prevalence of EDS by $14 \%$ among university health students. A recent study ${ }^{28}$ found that medical students who used cell phones for $>2$ hours daily had their melatonin circadian rhythms disturbed, because there was a negative correlation between the serum concentration of melatonin and the duration of smartphone use of. Melatonin secretion can be inhibited when the suprachiasmatic nucleus, which has a direct neural connection with the cells at the retinal base, receives feedback from the emission of blue light by smartphones (wavelength between $450-480 \mathrm{~nm}$ of the electromagnetic spectrum) by the melanopsin photopigment ${ }^{2,29}$. A clinical trial found that the use of lenses to block blue light two hours before bedtime for a week improved sleep quality in individuals with insomnia. Thus, screen time management should be stimulated in this population as an intervention measure to reduce the prevalence of $\mathrm{EDS}^{30}$.

From the educational point of view, there is a concern regarding academic performance and the students' sense of well-being when they realize they are progressing towards achieving their professional goals. Poor sleep quality increases the risk of low grades and stress ${ }^{31}$ and drowsiness is associated with a higher prevalence of burnout and higher scores of mental exhaustion ${ }^{32}$.

One of the limitations of the epidemiological design used in this study was that it was not possible to infer causality, since exposure and outcomes were measured simultaneously. The results, therefore, reflect an absence of temporal relationship; however, the impossibility for EDS to be the cause of the associated factors identified in this study limits the possibility of a reverse causality bias. Future studies will broaden our understanding of the quality of professional performance in former students with a high prevalence of EDS and the influence of EDS on traffic accidents that could have been prevented.

\section{CONCLUSION}

This study demonstrated that the morning chronotype behaved as an independent protective factor for circadian cycle disorders. Performing weekly physical activity reduces EDS in students with intermediate and evening chronotypes.

\section{ABBREVIATIONS}

EDS, Excessive Daytime Sleepiness

MEQ, Morningness-Eveningness Questionnaire

ESS, Epworth Sleepiness Scale

PR, Prevalence Ratio

95\% $\mathrm{Cl}$, 95\%Confidence Interval

IQR, Interquartile Range

\section{ETHICAL APPROVAL}

All procedures performed in studies involving human participants were in accordance with the ethical standards of the institutional and/or national research committee and with the 1964 Declaration of Helsinki and its later amendments or comparable ethical standards.

\section{AUTHORS' CONTRIBUTION}

Suellen Suemi Shimada invited the participants, applied the data collection instrument, digitized the answers into a database and revised the manuscript. Marília Rocha Kintschev invited the participants, applied the data collection instrument, digitized the answers into a database and revised the manuscript. 
Maria Olivia da Silva invited the participants, applied the data collection instrument, digitized the answers into a database and revised the manuscript. Yara Viñé de Barros invited the participants, applied the data collection instrument, digitized the answers into a database and revised the manuscript. Hugo Dias Hoffmann-Santos wrote the research project, submitted it to the ethics committee, created the database to store the responses of the collection instruments, analyzed the data and wrote the article.

\section{CONFLICTS OF INTEREST}

The authors declare no conflicts of interest.

\section{SOURCES OF FUNDING}

None of the researchers received financial support.

\section{REFERENCES}

1. Legnani RFS, Legnani E, Bacil EDA, da Silva MP, de Campos W. Hábitos de sono e prática habitual da atividade física em escolares: uma revisão sistemática. Rev Educ Fís UEM 2015;26(1):147-56. doi: 10.4025/reveducfis. v26i1.24864.

2. Jansen JM, Lope AJ, Jansen U, Capone D, Maeda TY, Noronha A, et al. Medicina da noite: da cronobiologia à prática clínica. Rio de Janeiro: Editora FIOCRUZ; 2007.

3. Correia FMS, de Albuquerque RN, Martins HAL, Lins LF, Lima MDC, Dias JMS, et al. Participation in nighttime activities in the genesis of depression in public school teachers from the State of Pernambuco, Brazil. Dement Neuropsychol. 2012 out/dez;6(4):276-85. doi: 10.1590/S198057642012 DN06040013.

4. Marqueze EC, da Silva MJ, Moreno CRC. Qualidade do sono, atividade física durante o tempo de lazer e esforço físico no trabalho entre trabalhadores noturnos de uma indústria de cerâmica. Rev Bras Saúde Ocup 2009;34(119):93-100. doi: 10.1590/S0303-76572009000100011.

5. Ribas VR, de Almeida CAV, Martins HAL, Alves CFO, Alves MJPC, Carneiro $\mathrm{SMO}$, et al. Brazilian air traffic controllers exhibit excessive sleepiness. Dement Neuropsychol 2011 jul/set;5(3):209-15. doi: 10.1590/S198057642011DN05030009.

6. Bittencourt LR, Silva RS, Santos RF, Pires MLN, de Mello MT. Sonolência excessiva. Rev Bras Psiquiatr 2005;27(supl I):16-21. doi: 10.1590/S151644462005000500004.

7. Ohayon MM. Epidemiology of excessive daytime sleepiness. Sleep Med Clin. 2006;1(1):9-16. doi: 10.1016/j.jsmc.2005.11.004.

8. Azevedo IG, Vieira EMA, Oliveira Neto NR, Nogueira IDB, de Melo FES, Nogueira PAMS. Correlação entre sono e qualidade de vida em pacientes com insuficiência cardíaca. Fisioter Pesq 2015;22(2):148-54. doi: 10.590/1809-2950/13828222022015.

9. Pedrosa R, Holanda G. Força muscular respiratória e capacidade funcional em idosas hipertensas com sonolência diurna excessiva. Fisioter Pesq 2010;17(2):118-23. doi: 10.1590/S1809-29502010000200005.

10. Martini M, Brandalize M, Louzada FM, Pereira EF, Brandalize D. Fatores associados à qualidade de sono em estudantes de fisioterapia. Fisioter Pesq 2012;19(3):261-7. doi: 10.1590/S1809-29502012000300012.

11. Rodrigues RND, Viegas CAA, Abreu e Silva AAA, Tavares P. Daytime sleepiness and academic performance in medical students. Arq Neuropsiquiatr 2002;60(1):6-11. doi: 10.1590/S0004-282X2002000100002.

12. Alam MF, Tomasi E, de Lima MS, Areas R, Menna-Barreto L. Caracterização e distribuição de cronótipos no sul do Brasil: diferenças de gênero e estação de nascimento. J Bras Psiquiatr 2008;57(2):83-90. doi: 10.1590/ S0047-20852008000200001.
13. Bertolazi AN, Fagondes SC, Hoff LS, Pedro VD, Menna-Barreto SS, Johns MW. Validação da escala de sonolência de Epworth em português para uso no Brasil. J Bras Pneumol 2009 set;35(9):877-83. doi: 10.1590/S180637132009000900009.

14. Barros AJD, Hirakata V. Alternatives for logistic regression in cross-sectional studies: an empirical comparison of models that directly estimate the prevalence ratio. BMC Med Res Method 2003;3:21. doi: 10.1186/14712288-3-21.

15. Young TB. Epidemiology of Daytime Sleepiness: definitions, symptomatology, and prevalence. J Clin Psychiatry 2004;65(suppl 16):12 6. PMID: 15575799.

16. Wing YK, Chen L. Cross-cultural epidemiology of daytime sleepiness: universality, diversity and definition issues [editorial]. Sleep Med 2009;10:164-6. doi: 10.1016/j.sleep.2008.06.002.

17. Hayley AC, Williams LJ, Kennedy GA, Berk M, Brennan SL, Pasco JA. Prevalence of excessive daytime sleepiness in a sample of the Australian adult population. Sleep Med 2014;15:348-54. doi: 10.1016/j. sleep.2013.11.783.

18. Hara C, Rocha FL, Lima-Costa MFF. Prevalence of excessive daytime sleepiness and associated factors in Brazilian community: the Bambuí study. Sleep Med 2004;5:31-6. doi: 10.1016/j.sleep.2003.09.009.

19. Silva MT, Roa MC, Martins SS, da Silva ATC, Galvao TF. Prevalence and correlates of depressive symptoms among adults living in the Amazon, Brazil: A population-baSDE study. J Affect Disord 2017;222:162-8. doi: 10.1016/j.jad.2017.06.053.

20. Bose J, Hedden SL, Lipari RN, Park-Lee E. Key substance use and mental health indicators in the United States: results from the 2015 National Survey on Drug Use and Health. Maryland: Substance Abuse and Mental Health Services Administration (SAMHSA); 2016. Contract No. HHSS283201300001C. Sponsored by the U.S. Department of Health and Human Services (HHS).

21. Shariati M, Yunesian M, Vash JH. Mental Health of Medical Students: A Cross-Sectional Study in Tehran. Psychological Reports. 2007;100(2):34654. doi:10.2466/pr0.100.2.346-354.

22. Kredlow MA, Capozzoli M, Hearon BA, Calkins AW, Otto MW. The effects of physical activity on sleep: a meta-analytic review. J Behav Med 2015;38(3):427-49. doi: 10.1007/s10865-015-9617-6.

23. Dikker S, Haegens S, Bevilacqua D, Davidesco I, Wan L, et al. Morning brain real-world neural evidence that high school class times matter. PsyArXiv, 12 May 2020. doi: 10.31234/osf.io/dxha5.

24. Erdinc O, Unal E, Aydin R, Uzuner G, Metintas S. The relationship between excessive daytime sleepiness and depression in medical students. Sleep Med 2015;16:S2-S199. doi: 10.1016/j.sleep.2015.02.1380.

25. Souza JC, Souza N, Arashiro ESH, Schaedler R. Sonolência diurna excessiva em pré-vestibulandos. J Bras Psiquiatr 2007;56(3):184-7. doi: 10.1590/ S0047-20852007000300005.

26. Machado-Duque ME, Chabur JEE, Machado-Alba JE. Somnolencia diurna excessiva, mala calidad del sueño y bajo rendimiento académico en estudiantes de Medicina. Rev Colomb Psiquiatr 2015;44(3):137-42. doi: 10.1016/j.rcp.2015.04.002.

27. Joo S, Shin C, Kim J, Yi H, Ahn Y, Park M, et al. Prevalence and correlates of excessive daytime sleepiness in high school students in Korea. Psych Clin Neuro 2005;59:433-40. doi: 10.1111/j.1440-1819.2005.01396.x.

28. Shrivastava A, Saxena Y. Effect of mobile usage on serum melatonin levels among medical students. Indian J Physiol Pharmacol 2014;58(4):395-9. PMID: 26215007.

29. Heo JY, Kim K, Fava M, Mischoulon D, Papakostas GI, Kim MJ, et al. Effects of smartphone use with and without blue light at night in healthy adults: A randomized, double-blind, cross-over, placebo-controlled comparison. J Psychiatr Res 2017;87:61-70. doi: 10.1016/j.jpsychires.2016.12.010.

30. Shechter A, Kim EW, St-Onge MP, Westwood AJ. Blocking nocturnal blue light for insomnia: A randomized controlled trial. J Psychiatr Res 2017;96:196-202. doi: 10.1016/j.jpsychires.2017.10.015. 
31. Almojali Al, Almalki SA, Alothman AS, Masuadi EM, Alaqeel MK. The prevalence and association of stress with sleep quality among medical students. J Epidemiol Glob Health. 2017;7(3):169-74. doi:10.1016/j. jegh.2017.04.005.
32. Wolf MR, Rosenstock JB. Inadequate Sleep and Exercise Associated with Burnout and Depression Among Medical Students. Acad Psychiatry. 2017;41(2):174-9. doi:10.1007/s40596-016-0526-y. 